\title{
SELECTING THE PROPER CONDITIONS FOR THRESHING LENTIL AND BEAN
}

\author{
Mahmoud M. A. Ali *
}

ABSTRACT

Filed experiments were carried out to select the optimum conditions for threshing both lentil and bean in order to minimize energy consumed and criterion cost under Egyptian conditions. All experiments were conducted under three variables for both lentil and bean: four material feed rates of (0.7, 0.75, 0.8 and 0.85) $\mathrm{Mg} / \mathrm{h}$ and (0.6, 0.65, 0.7 and 0.75) $\mathrm{Mg} / \mathrm{h}$, four drum speeds of 450, 480, 510 and $540 \mathrm{rpm}$ and 460, 490, 520 and 550 rpm and four seed moisture contents $(w b)$ of $(14.1,12.3,10.6$ and $9.7 \%)$ and $(13.5,12.4,10.2$ and $9.1 \%)$ for lentil and bean, respectively. Threshing machine performance was evaluated in terms of threshing losses, threshing and cleaning efficiency, energy requirements and criterion cost. The experimental results reveal to the following:

- The suitable feed rates to thresh lentil and bean were 0.8 and $0.7 \mathrm{Mg} / \mathrm{h}$, respectively.

- The proper drum speed for threshing lentil and bean were 510 and 520 rpm, respectively.

- The optimum seed moisture content suitable for threshing lentil and bean were 10.6 and $10.2 \%$, respectively.

\section{INTRODUCTION}

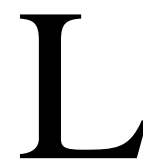
entil and bean are considered two of the most important legumes crops all over the world. Agricultural policy depends on the successful technology through mechanizing the agricultural processes of strategicall crops. Many researches are deducing in the scope of mechanical threshing of some crops such as: wheat, rice, soybean, peanut, lupine and chickpea. But threshing of lentil (lens exculenta) and bean (Phaseolus vulgaris L.) crops are still threshed manually in Egypt. The seeds of lentil contain $23.7 \%$ of protein and 45 $\%$ of carbohydrates. The total lentil cultivated area in Egypt are about 75238.1 feddan yearly producing about $45000 \mathrm{Mg}$ with an average yield of $0.598 \mathrm{Mg} / \mathrm{fed}$ according to http://www.reefnet.gov.sy/agri/lentils.

\footnotetext{
Assis. Prof. of Agric. Eng. Dept., Fac. of Agric., Zagazig Univ., Egypt.
} 
The seeds of bean contain 13 to $33 \%$ of protein, 40 to $55 \%$ of carbohydrates and 4 to $10 \%$ of oil, Stallknecht et al. (1995). The total bean cultivated area in Egypt devoted for dry seeds at 2010 are about 47000 feddans yearly producing about $53000 \mathrm{Mg}$ with an average yield of $1.13 \mathrm{Mg} /$ fed according to Agricultural Economic Bulletin(2010). In addition, both lentil and bean are considered two of the crops which play an important role in the improvement of soil properties especially in new reclaimed lands as they contains vitamins A and B. Lentil is currently used in human feeding dry seeds but bean is currently used in human feeding either green pods or dry seeds. More over lentil and bean residues serve as a filling material for animal feed. Greven et al. (2001) reported that the most common reason for poor seed quality in large seeded legumes were occur when seeds are threshed at unsuitable seed moisture content and at high drum speed. Souza et al. (2002) reported that the best seed germination, vigor and purity of bean seeds and also lowest seed damage were obtained with $14.1 \%$ seed moisture content and a threshing cylinder velocity of $420 \mathrm{rpm}$. Greven et al. (2004) stated that after harvesting but not threshing of bean seeds before maximum seed weight had been reached leaving seeds in the pod had a significant influence on final seed size and viability. The quality of bean seeds depends on many pre and post-harvest factors, such as area of production, cultivation techniques, seed maturity, harvest, threshing, and processing of storage conditions. Moussa (2006) studied the performance of threshing machine with three different legume crops (soybean, lentil and chickpea) in term of grain loss, grain damage, energy requirements and threshing cost as a function of change in cylinder speed 10, 12 and $14 \mathrm{~m} / \mathrm{s}$, feed rate $(600,800$ and $900 \mathrm{~kg} / \mathrm{h})$ and grain moisture content $(10$, 12.12 and $14.1 \%)$ for soybean, $(10.12,12.16$ and $13.78 \%)$ for lentil and $(9,10.7$ and $11.53 \%)$ for chickpea. He found that the highest values of grain damage were 1.63, 1.42 and $1.25 \%$ at feed rates of 600, 800 and $900 \mathrm{~kg} / \mathrm{h}$, respectively at drum speed of $14 \mathrm{~m} / \mathrm{s}$ and grain moisture content of $10.12 \%$. Also the highest values of un-threshed grain were $2.03,2.47$ and $3.0 \%$ at feed rates of 600,800 and $900 \mathrm{~kg} / \mathrm{h}$, respectively at drum speed of $10 \mathrm{~m} / \mathrm{s}$ and grain moisture content of $13.78 \%$ for lentil. The highest values of threshing efficiencies were $98.74,97.68$ and 97.46 
$\%$ at feed rates of 600,800 and $900 \mathrm{~kg} / \mathrm{h}$, respectively at drum speed of $14 \mathrm{~m} / \mathrm{s}$ and grain moisture content of $10.12 \%$ for lentil. The highest and lowest criterion costs of lentil were 190.15 and 126.1 L.E. /fed at drum speed of (550 and 500) rpm and grain moisture content of (13.78 and $10.12 \%)$, respectively. Morad, et. al. (2007) studied the threshing operation of cowpea crop at different drum speeds, and different seed moisture contents. They found that drum speed of $19.10 \mathrm{~m} / \mathrm{s}$ (500 r.p.m) and seed moisture content of $9.52 \%$ are considered the proper values for threshing cowpea crop as they recorded maximum efficiency, minimum energy and minimum cost. Zaalouk (2009) evaluated local machine performance for threshing dry bean. Threshing drum speeds tested were $11.72,13.18$ and $15.38 \mathrm{~m} / \mathrm{sec}$, feed rates of 10,15 and $20 \mathrm{~kg} / \mathrm{min}$ and seed was used at moisture contents of 13.56, 11.53 and $9.20 \%$. The obtained results show that, the local threshing machine can be successfully used for threshing bean under the following conditions: seed moisture content of $9.20 \%$ drum speed of $15.38 \mathrm{~m} / \mathrm{sec}$ and feed rate of $20 \mathrm{~kg} / \mathrm{min}$, resulting in seed damage of $2.17 \%$ and un-threshed seed of $1.48 \%$, threshing efficiency of $98.52 \%$, consumed power of $14.70 \mathrm{~kW}$ and criterion cost of 143.20 L.E /ton including operation and losses. Abd El-Atty, et. al.(2012) investigated the threshing operation of bean under three different drum speeds of 400, 500 and $600 \mathrm{rpm}$ and three moisture contents $(\mathrm{db})$ of $8.61,11.33$ and $17.82 \%$ at a constant feed rate of 185 $\mathrm{kg} / \mathrm{h}$. He found that the optimum conditions for threshing bean were drum speed of $500 \mathrm{rpm}$ and moisture content (db) of $11.33 \%$. Suleiman et. al. (2012) stated that bean seeds were removed by hand or by mechanical threshing at different seed moisture contents from $20 \%$ down to $11 \%$. The lowest percentage of normal seedlings and significantly higher abnormal seedlings, as well as a higher incidence of cracked seed coats were found for machine threshed seeds at below 14\% SMC. The field emergence at two sites showed evidence of reduced emergence in seeds that had been machine threshed at 11\% SMC. These findings showed that bean seeds should not be harvested and threshed by machine at below 14\% SMC if seed quality is to be maintained. This work has turned toward concept of mechanical threshing of lentil and bean. The objectives of this study are to select the optimum conditions for the 
threshing operation of lentil and bean (feed rate, drum speed and seed moisture content) to minimize energy consumed and criterion cost under Egyptian conditions.

\section{MATERIALS AND METHOD}

The main field experiments were carried out for threshing lentil (Giza 51 variety) and bean (Giza 6 variety) crops in a private farm in Sharkia governorate during the agricultural seasons of 2011 and 2012 to select the optimum conditions for threshing lentil and bean. All experiments were conducted using a threshing Turkish type machine. The elevation and plan of Turkish thresher machine are shown in Fig. (1).

\section{MATERIALS:}

\section{Threshing machine:}

\begin{tabular}{|l|l|l|l|}
\hline Made & Turkish & & \\
\hline Type of drum & Beater fingers & Concave holes $\left(\right.$ No. $\left./ 100 \mathbf{c m}^{2}\right)$ & 18 \\
\hline Drum diameter $(\mathrm{cm})$ & $\mathbf{7 3}$ & Concave hole diameter $(\mathrm{cm})$ & 1.8 \\
\hline Drum length $(\mathrm{cm})$ & 120 & Screen holes $\left(\right.$ No. $\left./ 100 \mathbf{c m}^{2}\right)$ & 40 \\
\hline Concave clearance $(\mathrm{cm})$ & 3 & Screen holes diameter $(\mathrm{cm})$ & 1.4 \\
\hline
\end{tabular}

The threshing machine was powered with Naser M34/T tractor with a four cylinder diesel engine $-60 \mathrm{hp}(44.10 \mathrm{~kW})$.

\section{METHOD:}

All experiments were conducted under three variables for lentil and bean: four material feed rates of $(0.7,0.75,0.8$ and 0.85$) \mathrm{Mg} / \mathrm{h}$ and $(0.6,0.65$, 0.7 and 0.75$) \mathrm{Mg} / \mathrm{h}$, four drum speeds of 450 (9.42), 480 (10.05), 510 (10.67) and $540(11.3) \mathrm{rpm}(\mathrm{m} / \mathrm{s})$ and 460 (9.63), $490(10.62), 520$ (10.89) and $550(11.51) \mathrm{rpm}(\mathrm{m} / \mathrm{s})$, respectively and four seed moisture contents (wb) of $(14.1,12.3,10.6$ and $9.7 \%)$ and (13.5, 12.4, 10.2 and $9.1 \%$ ) for lentil and bean, respectively. The seed moisture content was determined on wet basis using the oven method at $105^{\circ} \mathrm{C}$ for 24 hours in the laboratory of Faculty of Agriculture, Zagazig University.

\section{1-Threshing losses:}

The threshing losses percentage (TL) including both un-threshed seed $\left(U_{n} S\right.$ ) and mechanical seed damage $(M S D)$ was calculated using the following equation, (Mishram and Desta 1990):-

$$
T L,(\%)=\frac{U n S+M S D}{T_{S}} \times 100 .
$$




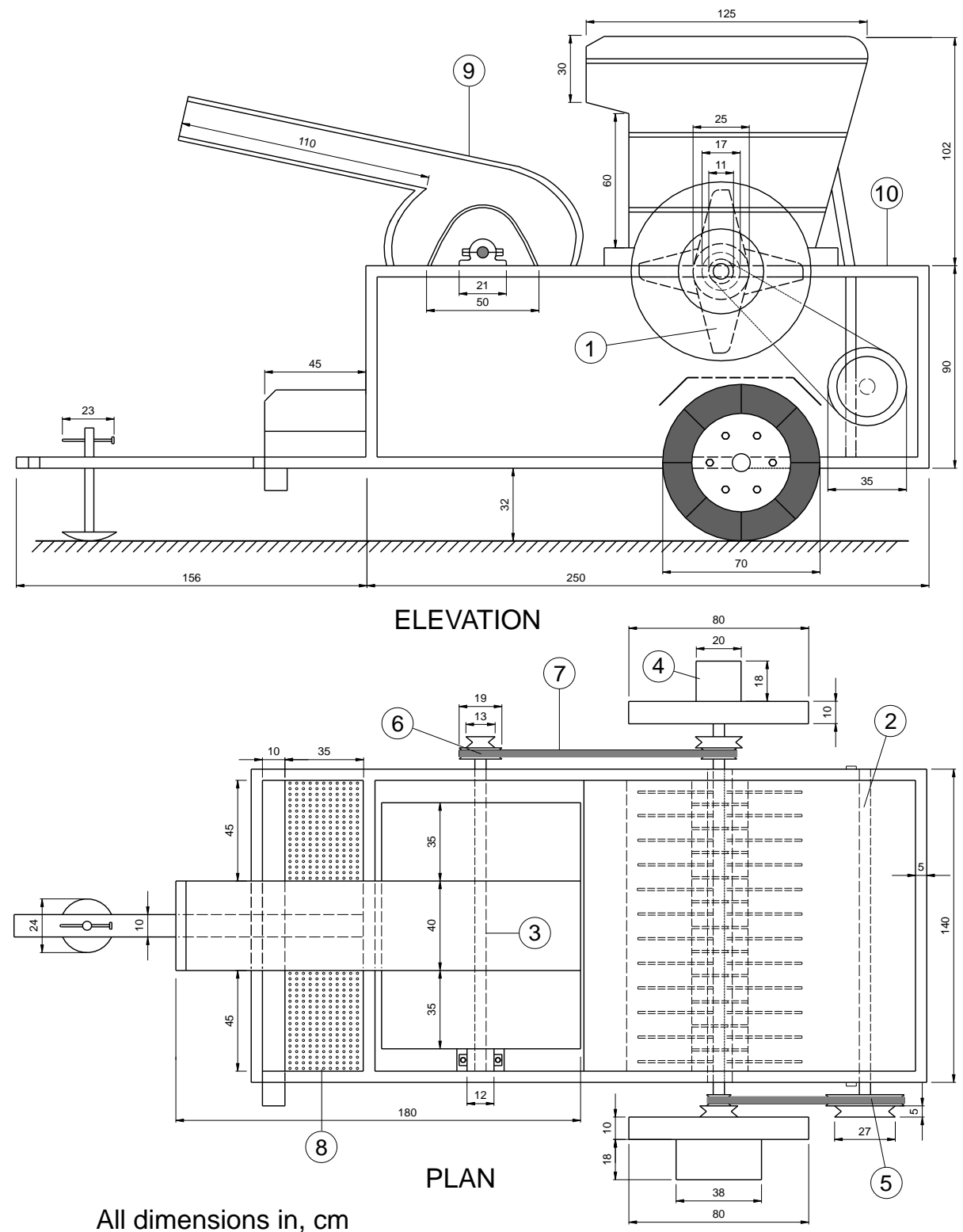

All dimensions in, $\mathrm{cm}$

\begin{tabular}{|c|c|c|c|c|c|}
\hline No. & Part name & No. off & No. & Part name & No. off \\
\hline 1 & Threshing drum & 1 & 6 & Fan pulley & 1 \\
\hline 2 & Sieve shaft & 1 & 7 & V-Belt & 2 \\
\hline 3 & Fan shaft & 1 & 8 & Sieve & 1 \\
\hline 4 & Wheat pulley & 1 & 9 & Blower & 1 \\
\hline 5 & Sieve pulley & 1 & 10 & Frame & 1 \\
\hline
\end{tabular}

Fig. (1): Elevation and plan of a Turkish threshing machine. 
Where:

$U n S=$ mass of un-threshed seeds per unit time, $\mathrm{kg}$.

$M S D=$ mass of damaged seeds collected at all outlets per unit time, $\mathrm{kg}$.

$T_{S}=$ mass of total seeds input per unit time, $\mathrm{kg}$.

Un-threshed seed percentage was calculated as follows:-

$$
U n S,(\%)=\frac{U n S}{T_{S}} \times 100
$$

Mechanical seed damaged percentage was calculated as follows:-

$$
M S D,(\%)=\frac{M S D}{T_{S}} \times 100
$$

\section{2-Threshing and cleaning efficiencies:}

Both threshing and cleaning efficiencies were calculated according to the following equation:-

$$
\begin{gathered}
\text { Threshing efficiency, }(\%)=\frac{T_{S}-U n S}{T_{S}} \times 100 \ldots . .(4) \\
\text { Cleaning efficiency, }(\%)=\frac{W}{W_{O}} \times 100 \ldots \ldots \ldots \ldots \text { (5) }
\end{gathered}
$$

Where:-

$W=$ mass of seeds from the main output opening after cleaning, $\mathrm{kg}$.

$W_{O}=$ mass of seeds and small chaff from the main output opening, $\mathrm{kg}$.

\section{3-Energy requirements:}

To estimate the engine power during threshing process, the decrease in fuel level is accurately measured immediately after each treatment. The following formula was used to estimate the corresponding used engine power $(E P)$ according to Hunt (1983).

$$
E P=\left[f . c .(1 / 3600) P E \times L . C . V . \times 427 \times \eta_{t h b} \times \eta_{m} \times 1 / 75 \times 1 / 1.36\right], k W \ldots .
$$

Solving equation (6), the engine power can be calculated as following:

Engine power(Diesel) $=3.16 f . c ., k W$.

Where:-

f.c. $=$ The fuel consumption, $(l / \mathrm{h})$.

$P E=$ The density of fuel, $(\mathrm{kg} / l)$, (for Gas oil $=0.85)$.

L.C. $V .=$ The lower calorific value of fuel, $(11.000 \mathrm{k} . c a l / \mathrm{kg})$.

$\eta_{t h b}=$ Thermal efficiency of the engine (35\% for Diesel).

427 = Thermo-mechanical equivalent, (kg.m/k.cal). 
$\eta_{m}=$ Mechanical efficiency of the engine (^ґ \% for Diesel).

Hence, the energy requirements can be calculated as follows:-

$$
\text { Energy requirements }=\frac{E P,(k W)}{\text { Feed rate },(M g / h)}, k W . h / M g .
$$

\section{4- Threshing cost:}

The total cost of threshing operation was estimated using the following equation, (Awady et al. 1982):-

Threshing cost, (L.E/ Mg) = Operating cost + Grain losses cost....(8)

Operating cost was determined using the following equation:-

$$
\text { Operating } \cos t=\frac{\text { Machine } \cos t(L . E / h)}{\text { Feed rate }(M g / h)},(L . E / M g) \text {. }
$$

Machine cost could be determined using the following equation (Awady 1978):-

$$
C=\frac{P}{h}\left(\frac{1}{a}+\frac{i}{2}+t+r\right)+(1.2 W \cdot S . F)+\frac{m}{144}
$$

Where:-

$C=$ Hourly cost, L.E/h.

$h=$ Yearly working hours, h/year.

$i=$ Interest rate/year.

$t=$ Taxes, over heads ratio.

$m=$ Monthly average wage, L.E

$W=$ Engine power, $\mathrm{hp}$.
$P=$ Price of machine, L.E.

$a=$ Life expectancy of the machine, $\mathrm{h}$.

$F=$ Fuel price, L.E/l.

$r=$ Repairs and maintenance ratio.

$0.9=$ Factor accounting for lubrications.

$S=$ Specific fuel consumption, $l / h p . h$.

$144=$ Reasonable estimation of monthly working hours.

\section{RESULTS AND DISCUSSION}

Discussion will cover the results obtained under the following headings

\section{1- Un-threshed, mechanical seed damaged, threshing losses, threshing efficiency and cleaning efficiency:}

The un-threshed seeds as well as mechanical seed damaged are affected by many parameters such as material feed rate, threshing drum speed, grain moisture content, .....etc.

1-1- Effect of material feed rate on un-threshed, mechanical seed damage, threshing losses, threshing efficiency and cleaning efficiency:

Results in Fig. (2) show the effect of lentil feed rate on the percentage of un-threshed seeds. Increasing lentil feed rate increased the percentage of 
un-threshed seeds and decreased the percentage of mechanical seeds damage under all experimental conditions. Increasing feed rate from 0.7 to $0.85 \mathrm{Mg} / \mathrm{h}$, increased the un-threshed seeds from 2.41 to $4.09 \%$, from 1.42 to $2.72 \%$, from 1.05 to $2.17 \%$ and from 0.69 to $1.93 \%$, under constant drum speed of $510 \mathrm{rpm}$ and different seed moisture contents of $14.1,12.3,10.6$ and $9.7 \%$, respectively. While, increasing feed rate from 0.7 to $0.85 \mathrm{Mg} / \mathrm{h}$, decreased mechanical seeds damage from 4.28 to 1.77 $\%$, from 4.89 to $2.51 \%$, from 5.02 to $2.91 \%$ and from 6.22 to $4.1 \%$, under the same previous conditions. Relating to the effect of lentil feed rate on the percentage of threshing losses, Fig. (2) shows that increasing feed rate, decreased threshing losses up to $0.8 \mathrm{Mg} / \mathrm{h}$. Any further feed rate increase, up to $0.85 \mathrm{Mg} / \mathrm{h}$, increased threshing losses. Increasing feed rate from 0.7 to $0.85 \mathrm{Mg} / \mathrm{h}$, decreased threshing losses from 6.69 to $5.86 \%$, from 6.31 to $5.23 \%$, from 6.07 to $5.08 \%$, and from 6.91 to $6.03 \%$, under constant drum speed of $510 \mathrm{rpm}$ and different seed moisture contents of 14.1, 12.3, 10.6 and $9.7 \%$, respectively.

Results in Fig. (2) show the effect of lentil feed rate on the percentage of threshing efficiency and cleaning efficiency. Increasing lentil feed rate decreased both the percentage of threshing and cleaning efficiencies under all experimental conditions. Increasing feed rate from 0.7 to $0.85 \mathrm{Mg} / \mathrm{h}$, decreased threshing efficiency from 97.59 to $95.91 \%$, from 98.58 to $97.28 \%$, from 98.95 to $97.83 \%$ and from 99.31 to $98.07 \% \%$, under constant drum speed of $510 \mathrm{rpm}$ and different seed moisture contents of $14.1,12.3,10.6$ and $9.7 \%$, respectively. Also, increasing feed rate from 0.7 to $0.85 \mathrm{Mg} / \mathrm{h}$, decreased cleaning efficiency from 96.08 to $92.54 \%$, from 97.04 to $94.42 \%$, from 97.84 to $95.22 \%$ and from 98.44 to 96.03 $\% \%$, under the same previous conditions.

Results in Fig. (2) show the effect of bean feed rate on the percentage of un-threshed seeds. Increasing bean feed rate increased the percentage of un-threshed seeds and decreased the percentage of mechanical seeds damage under all experimental conditions. Increasing feed rate from 0.6 to $0.75 \mathrm{Mg} / \mathrm{h}$, increased the un-threshed seeds from 2.67 to $4.15 \%$, from 1.51 to $2.91 \%$, from 1.12 to $2.44 \%$ and from 0.74 to $1.95 \%$, under constant drum speed of $520 \mathrm{rpm}$ and different seed moisture contents of $13.5,12.4,10.2$ and $9.1 \%$, respectively. While, increasing feed rate from 


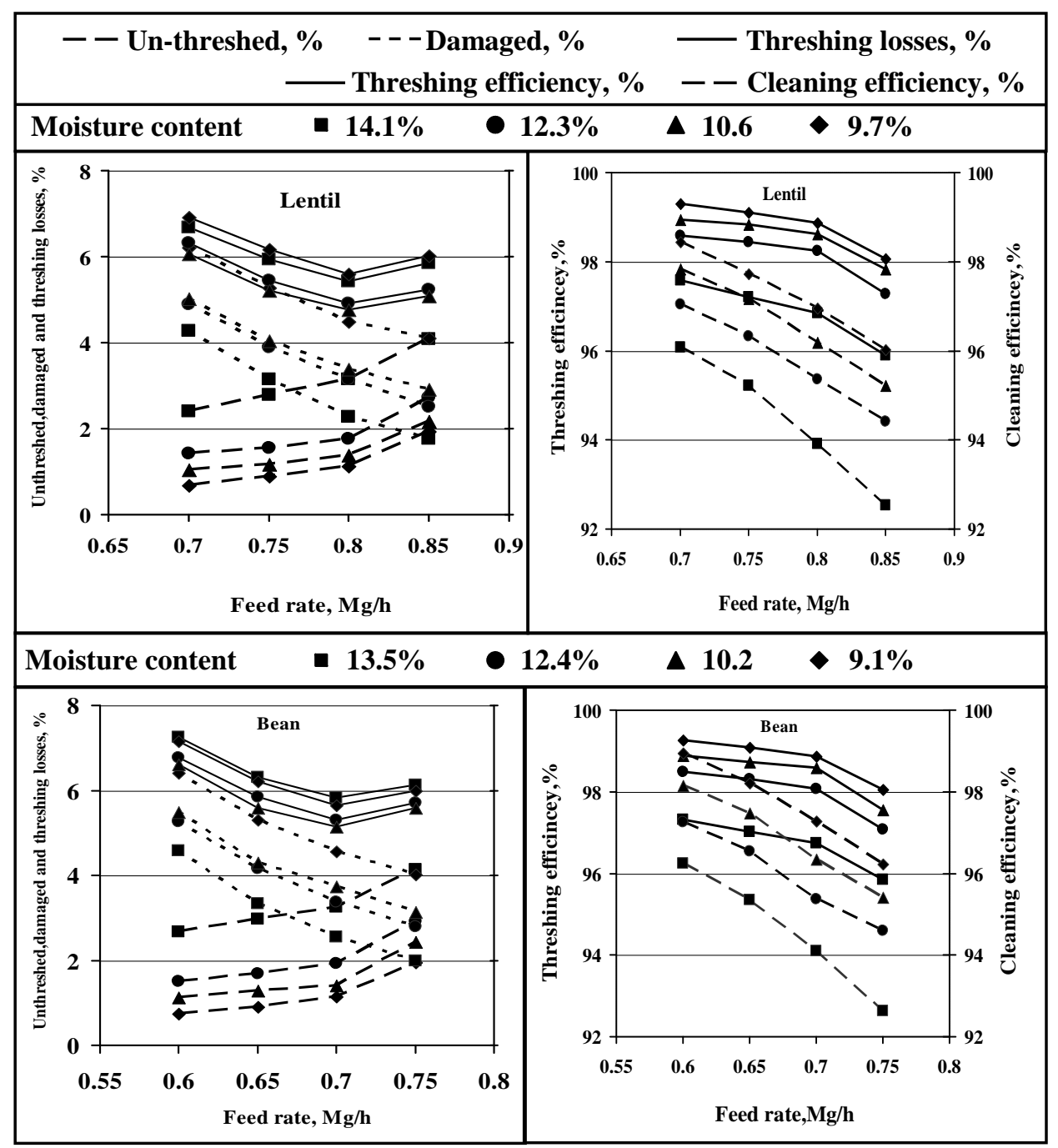

Fig (2): Effect of lentil and bean feed rate on un-threshed, damaged, threshing losses, threshing efficiency and cleaning efficiency under different seed moisture contents (D.S. $=510 \mathrm{rpm}$ for lentil and $520 \mathrm{rpm}$ for bean).

0.6 to $0.75 \mathrm{Mg} / \mathrm{h}$, decreased mechanical seeds damage from 4.59 to 1.98 $\%$, from 5.26 to $2.8 \%$, from 5.49 to $3.14 \%$ and from 6.41 to $4.03 \%$, under the same previous conditions. Relating to the effect of bean feed rate on the percentage of threshing losses, Fig. (2) show that increasing feed rate, decreased threshing losses up to $0.7 \mathrm{Mg} / \mathrm{h}$. Any further feed rate increase, up to $0.75 \mathrm{Mg} / \mathrm{h}$, increased threshing losses. Increasing feed rate 
from 0.6 to $0.75 \mathrm{Mg} / \mathrm{h}$, decreased threshing losses from 7.26 to $6.13 \%$, from 6.77 to $5.71 \%$, from 6.61 to $5.58 \%$, and from 7.15 to $5.98 \%$, under constant drum speed of $520 \mathrm{rpm}$ and different seed moisture contents of 13.5, 12.4, 10.2 and $9.1 \%$, respectively.

Results in Fig. (2) show the effect of bean feed rate on the percentage of threshing efficiency and cleaning efficiency. Concerning increasing bean feed rate decreased both the percentage of threshing and cleaning efficiency under all experimental conditions. Increasing feed rate from 0.6 to $0.75 \mathrm{Mg} / \mathrm{h}$, decreased threshing efficiency from $97 . \mathrm{r}$ to $95.85 \%$, from 98.49 to $97.09 \%$, from 98.88 to $97.56 \%$ and from 99.26 to $98.05 \%$, under constant drum speed of $520 \mathrm{rpm}$ and different seed moisture contents of 13.5, 12.4, 10.2 and $9.1 \%$, respectively. Also, increasing feed rate from 0.6 to $0.75 \mathrm{Mg} / \mathrm{h}$, decreased cleaning efficiency from 96.24 to $92.64 \%$, from 97.26 to $94.61 \%$, from 98.15 to $95.41 \%$ and from 98.94 to $96.23 \%$, under the same previous conditions.

\section{1-2- Effect of drum speed on un-threshed, mechanical seed damage, threshing losses, threshing efficiency and cleaning efficiency:}

Results in Fig. (3) show the effect of drum speed on the percentage of unthreshed seeds. Increasing drum speed, decreased the percentage of unthreshed seeds and increased the percentage of mechanical seeds damage under all experimental conditions. Increasing drum speed from 450 to 540 rpm, decreased the un-threshed seeds from 5.73 to $2.11 \mathrm{rpm}$, from 4.67 to $1.46 \mathrm{rpm}$, from 4.11 to $1.03 \mathrm{rpm}$ and from 3.45 to $0.78 \mathrm{rpm}$, under constant lentil feed rate of $0.8 \mathrm{Mg} / \mathrm{h}$, and different seed moisture contents of $14.1,12.3,10.6$ and $9.7 \%$, respectively. While, increasing drum speed from 450 to $540 \mathrm{rpm}$ increased mechanical seeds damage from 0.76 to $3.86 \mathrm{rpm}$, from 1.62 to $4.13 \mathrm{rpm}$, from 1.87 to $4.38 \mathrm{rpm}$ and from 3.22 to $5.36 \mathrm{rpm}$, under the same previous conditions. Relating to the effect of drum speed on the percentage of threshing losses. Fig. (3) shows that increasing drum speed, decreased threshing losses up to $510 \mathrm{rpm}$. Any further drum speed increase, up to $540 \mathrm{rpm}$, increased threshing losses. Increasing drum speed from 450 to $540 \mathrm{rpm}$ decreased threshing losses from 6.49 to $5.97 \%$, from 6.29 to $5.59 \%$, from 5.98 to $5.41 \%$, and from 


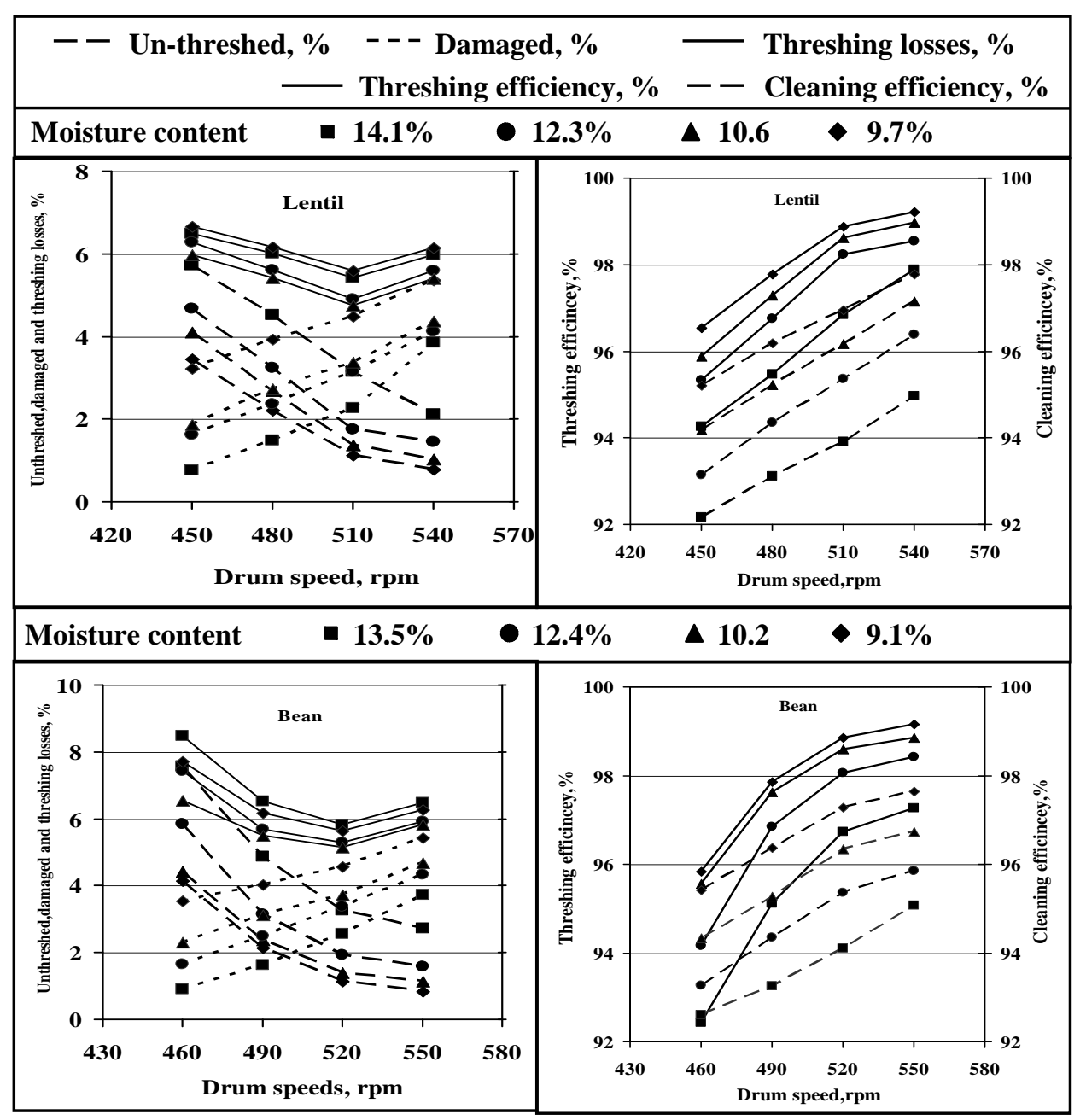

Fig (3): Effect of drum speed on un-threshed, damaged, threshing losses, threshing efficiency and cleaning efficiency under different seed moisture contents (F.R. $=0.8 \mathrm{Mg} / \mathrm{h}$ for lentil and $0.7 \mathrm{Mg} / \mathrm{h}$ for bean).

6.67 to $6.14 \%$ under constant lentil feed rate of $0.8 \mathrm{Mg} / \mathrm{h}$, and different seed moisture contents of 14.1, 12.3, 10.6 and $9.7 \%$, respectively. Results in Fig. (3) show the effect of drum speed on the percentage of threshing efficiency and cleaning efficiency. Increasing drum speed, increased both the percentage of threshing and cleaning efficiency under all experimental conditions. Increasing drum speed from 450 to $540 \mathrm{rpm}$ increased threshing efficiency from 94.27 to $97.89 \%$, from 95.33 to $98.54 \%$, from 
95.89 to $98.97 \%$ and from 96.55 to $99.22 \%$, under constant lentil feed rate of $0.8 \mathrm{Mg} / \mathrm{h}$, and different seed moisture contents of 14.1, 12.3, 10.6 and $9.7 \%$, respectively. Also, increasing drum speed from 450 to $540 \mathrm{rpm}$, increased cleaning efficiency from 92.17 to $94.97 \%$, from 93.14 to 96.39 $\%$, from 94.18 to $97.15 \%$ and from 95.21 to $97.78 \%$, under the same previous conditions.

Results in Fig. (3) show the effect of drum speed on the percentage of unthreshed seeds. Increasing drum speed, decreased the percentage of unthreshed seeds and increased the percentage of mechanical seeds damage under all experimental conditions. Increasing drum speed from 460 to 550 rpm decreased the un-threshed seeds from 7.57 to $2.73 \mathrm{rpm}$, from 5.84 to $1.58 \mathrm{rpm}$, from 4.43 to $1.14 \mathrm{rpm}$ and from 4.16 to $0.84 \mathrm{rpm}$, under constant bean feed rate of $0.7 \mathrm{Mg} / \mathrm{h}$, and different seed moisture contents of 13.5, 12.4, 10.2 and $9.1 \%$, respectively. While, increasing drum speed from 460 to $550 \mathrm{rpm}$ increased mechanical seeds damage from 0.91 to $3.74 \mathrm{rpm}$, from 1.65 to $4.34 \mathrm{rpm}$, from 2.31 to $4.69 \mathrm{rpm}$ and from 3.55 to $5.42 \mathrm{rpm}$, under the same previous conditions. Relating to the effect of drum speed on the percentage of threshing losses. Fig.(3) show that increasing drum speed, decreased threshing losses up to $520 \mathrm{rpm}$. Any further drum speed increase, up to $550 \mathrm{rpm}$, increased threshing losses. Increasing drum speed from 460 to $550 \mathrm{rpm}$ decreased threshing losses from 8.48 to $6.47 \%$, from 7.44 to $5.92 \%$, from 6.54 to $5.83 \%$, and from 7.71 to $6.26 \%$ under constant bean feed rate of $0.7 \mathrm{Mg} / \mathrm{h}$, and different seed moisture contents of 13.5, 12.4, 10.2 and $9.1 \%$, respectively. Results in Fig. (3) show the effect of drum speed on the percentage of threshing efficiency and cleaning efficiency. Increasing drum speed, increased both the percentage of threshing and cleaning efficiency under all experimental conditions. Increasing drum speed from 460 to $550 \mathrm{rpm}$ increased threshing efficiency from 92.43 to $97.27 \%$, from 94.16 to $98.42 \%$, from 95.57 to $98.86 \%$ and from 95.84 to $99.16 \%$, under constant bean feed rate of $0.7 \mathrm{Mg} / \mathrm{h}$, and different seed moisture contents of 13.5, 12.4, 10.2 and $9.1 \%$, respectively. Also, Increasing drum speed from 460 to 550 rpm, increased cleaning efficiency from 92.61 to $95.08 \%$, from 93.27 to $95.86 \%$, from 94.34 to $96.74 \%$ and from 95.42 to $97.64 \%$, under the same previous conditions. 


\section{2- Energy requirements:}

The energy requirements are a measure for all parameters affecting the threshing operation. It increased as increasing the material feed rate, threshing drum speed and seed moisture content.

\section{2-1- Effect of material feed rate on energy requirements:}

Results obtained in Fig. (4) show that increasing lentil feed rate increased the value of energy requirements under all experimental conditions. Increasing feed rate from 0.7 to $0.85 \mathrm{Mg} / \mathrm{h}$, increased the percentage of energy requirements by $7.69 \%, 5.02,3.4$ and $5.42 \%$, under constant drum speed of $510 \mathrm{rpm}$ and different seed moisture contents of 14.1, 12.3, 10.6 and $9.7 \%$, respectively. Results obtained in Fig. (4) show that increasing bean feed rate increased the value of energy requirements under all experimental conditions. Increasing feed rate from 0.6 to $0.75 \mathrm{Mg} / \mathrm{h}$, increased the percentage of energy requirements by $6.32 \%, 4.21,7.1$ and $5.68 \%$, under constant drum speed of $520 \mathrm{rpm}$ and different seed moisture contents of $13.5,12.4,10.2$ and $9.1 \%$, respectively. The increase in the percentage of energy requirements by increasing material feed rate is attributed to the excessive lentil and bean materials in the threshing chamber, that increase the load on the threshing drum caused more fuel consumed.

\section{2-2- Effect of drum speed on energy requirements:}

Results obtained in Fig. (4) show that increasing drum speed increased the value of energy requirements under all experimental conditions. Increasing feed rate from 450 to $540 \mathrm{rpm}$, increased the percentage of energy requirements by $9.97 \%, 8.14,7.81$ and $7.18 \%$, under constant lentil feed rate $0.8 \mathrm{Mg} / \mathrm{h}$, and different seed moisture contents of 14.1, 12.3, 10.6 and $9.7 \%$, respectively. Results obtained in Fig. (4) show that increasing drum speed increased the value of energy requirements under all experimental conditions. Increasing drum speed from 460 to $550 \mathrm{rpm}$, increased the percentage of energy requirements by $9.2 \%, 13.43,13.7$ and $12.27 \%$, under constant bean feed rate $0.7 \mathrm{Mg} / \mathrm{h}$, and different seed moisture contents of $13.5,12.4,10.2$ and $9.1 \%$, respectively.

\section{3- Criterion cost:}

\section{3-1- Effect of material feed rate on Criterion cost:}

Relating to the effect of lentil feed rate on criterion cost. Fig. (4) show 


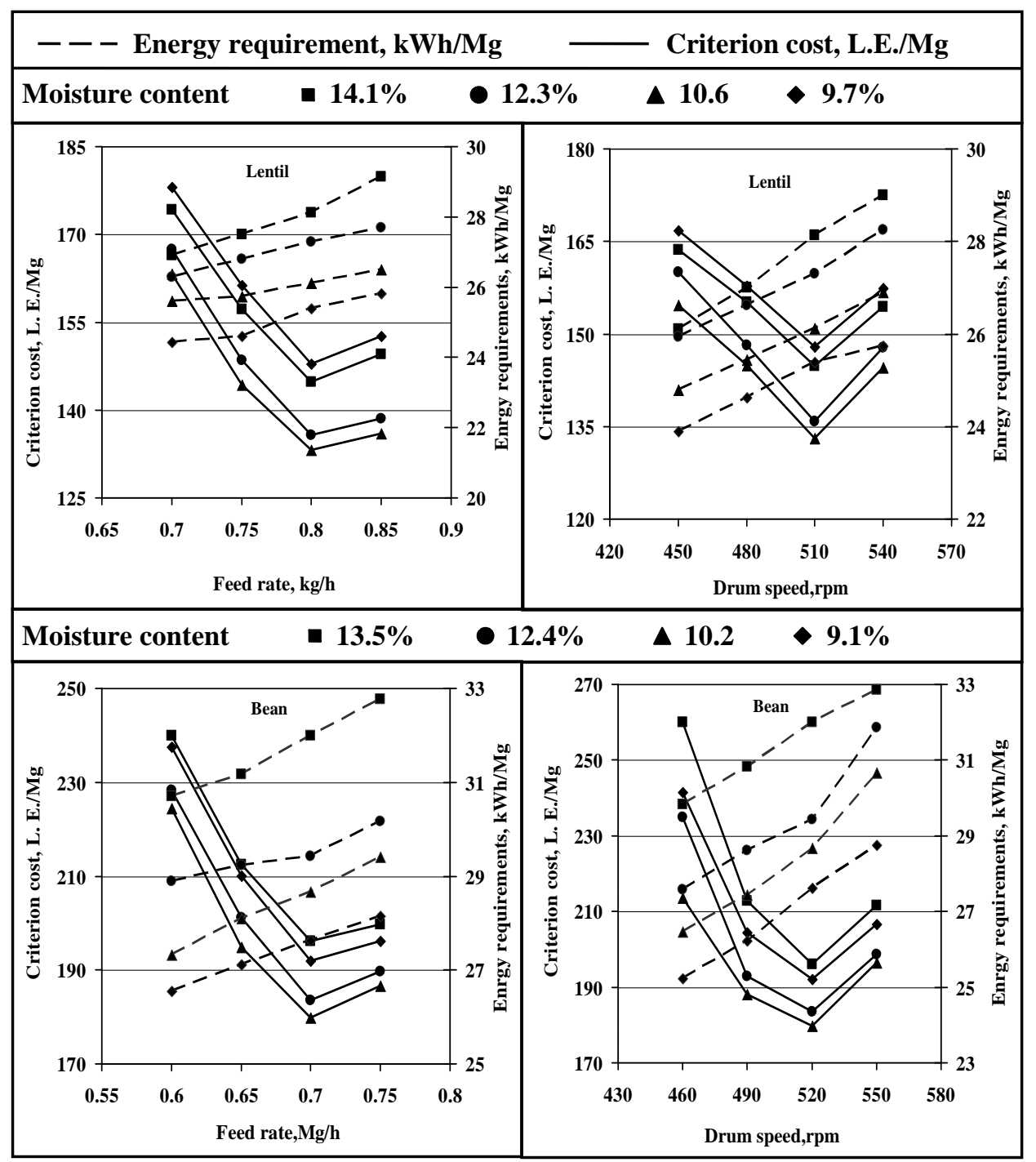

Fig (4): Effect of feed rate and drum speed on energy requirement and Criterion cost under different seed moisture contents.

that increasing feed rate, decreased criterion cost up to $0.8 \mathrm{Mg} / \mathrm{h}$. Any further feed rate increase, up to $0.85 \mathrm{Mg} / \mathrm{h}$, increased criterion cost. Increasing feed rate from 0.7 to $0.85 \mathrm{Mg} / \mathrm{h}$, decreased criterion cost from 174.2 to 149.6 L.E./Mg, from 167.5 to 138.5 L.E./Mg, from 163.3 to 136 L.E./Mg, and from 178.04 to 152.6 L.E./Mg, under constant drum speed of $510 \mathrm{rpm}$ and different seed moisture contents of 14.1, 12.3, 10.6 and 9.7 $\%$, respectively. Relating to the effect of bean feed rate on criterion cost. 
Fig. (4) show that increasing feed rate, decreased criterion cost up to 0.7 $\mathrm{Mg} / \mathrm{h}$. Any further feed rate increase, up to $0.75 \mathrm{Mg} / \mathrm{h}$, increased criterion cost. Increasing feed rate from 0.6 to $0.75 \mathrm{Mg} / \mathrm{h}$, decreased criterion cost from 240.01 to 199.8 L.E./Mg, from 228.33 to 189.73 L.E./Mg, from 224.5 to 186.6 L.E./Mg, and from 237.5 to 196.2 L.E./Mg, under constant drum speed of $520 \mathrm{rpm}$ and different seed moisture contents of $13.5,12.4,10.2$ and $9.1 \%$, respectively.

\section{3-2- Effect of drum speed on Criterion cost:}

Relating to the effect of drum speed on criterion cost. Fig. (4) shows that increasing drum speed, decreased criterion cost up to $510 \mathrm{rpm}$. Any further drum speed increase, up to $540 \mathrm{rpm}$, increased criterion cost. Increasing drum speed from 450 to $540 \mathrm{rpm}$ decreased criterion cost from 163.6 to $154.45 \%$, from 160.1 to $147.8 \%$, from 154.63 to $144.6 \%$, and from 166.76 to $157.4 \%$ under constant lentil feed rate of $0.8 \mathrm{Mg} / \mathrm{h}$, and different seed moisture contents of 14.1, 12.3, 10.6 and $9.7 \%$, respectively. Relating to the effect of drum speed on criterion cost. Fig. (4) shows that increasing drum speed, decreased criterion cost up to 520 rpm. Any further drum speed increase, up to $550 \mathrm{rpm}$, increased criterion cost. Increasing drum speed from 460 to $550 \mathrm{rpm}$ decreased criterion cost from 260 to $211.71 \%$, from 235 to $198.6 \%$, from 213.6 to $196.43 \%$, and from 241.5 to $206.71 \%$ under constant bean feed rate of $0.7 \mathrm{Mg} / \mathrm{h}$, different seed moisture contents of $13.5,12.4,10.2$ and $9.1 \%$, respectively.

\section{CONCLUSION}

The field experiments aim to select the optimum conditions for the threshing operation of lentil and bean to minimize energy consumed and criterion cost under Egyptian conditions. The field experiments were carried out for threshing lentil and bean crops in a private farm in Sharkia governorate during the agricultural seasons of 2011 and 2012 to investigate some different systems using a threshing Turkish type machine. Results showed that the threshing efficiency were maximum while both threshing losses and criterion cost were minimum for lentil and bean, respectively under the following conditions:

- The proper feed rates are 0.8 and $0.7 \mathrm{Mg} / \mathrm{h}$.

- The proper drum speeds are 510 and $520 \mathrm{rpm}$.

- The optimum seed moisture contents are 10.6 and $10.2 \%$. 


\section{REFERANCES}

Abd El-Atty, A. A. A; M. A. Hassan; M; K. Afify and Hanan M. ElShal (2012) Study on the mechanization of bean (Phaseolus vulgaris) crop under Egyptian condition. Zagazig J. Agric. Res., Vol. 39 No. (3) 2012: 529-538.

Agricultural Economic Bulletin (2010): Ministry of Agriculture, Cairo, Egypt.

Awady, M. N. (1978): Tractor and farm machinery. Text book, Faculty of Agriculture, Ain-Shams University, Cairo, Egypt. Pp: 164-167.

Awady, M. N; E. Y. Ghoniem and A. I. Hashish (1982): A critical comparison between wheat combine harvesters under Egyptian conditions. R. S. No. 1920, Ain-Shams Univ. J. 1982.

Greven, M. M; B. A. McKenzie; J. G. Hampton; M. J. Hill and G.D. Hill (2001): Some factors affecting seed quality during the mechanical threshing of dwarf French bean (Phaseolus vulgaris L.). Agronomy New Zealand, 31: 121-126.

Greven, M. M; B. A. McKenzie; J. G. Hampton; M. J. Hill; J. R. Sedcole and G. D. Hill (2004). Factors affecting seed quality in dwarf French bean (Phaseolus vulgaris L.) before harvest maturity. Seed Science and Technology, 32: 797-811.

Herat, L. G. (1992): Effects of maturity and seed size on seed vigor and plant growth in snap bean (Phaseoulus vulgaris L.). Ph.D. Thesis, Virginia Polytechnic Institute and State University, pp.117

Hunt, D. (1983): Farm power and machinery management. $8^{\text {th }}$ Ed. Iowa state Univ., Press Ames, USA. Ames, Iowa, USA: 364-368.

Mishram, T. N. and K. Desta (1990): Development and performance evaluation of a sorghum thresher. Agric. Mech. In ISIA, 21 (3): 33-37.

Morad, M. M; A. S. El-Kot, M. M. Ali, H. M. Salem (2007): Study on the mechanization of cowpea crop production under Egyptian conditions. Misr J. Agric. Eng., 24(3) : 450-467.

Moussa, A. I. (2006): The effect of selected mechanical threshing parameters on threchability of some legume crops. J. Agric. Sci. Mansoura Univ., 31(7): 1-24. 
Souza, C. M. A; D. M. Queiroz; E.C. Mantovani and P.R. Cecon (2002): Effect of mechanical harvesting on the quality of seeds of bean (Phaseolus vulgaris L.). Revista Brasileira de Armazenamento, 27(1): 21-29

Stallknecht, G; K. M. Gilbertson, G. R. Carlson, J. L. Eckhoff, G. D. Kushnak, J. R. Sims, M. P. Westcott and D. M. Wichman (1995): Production of Chickpeas in Montana. Montana Agr. Res.12:46-50.

Suleiman, K; L. Hulya; E. Benian; A. Alison and M. Stanley (2012): Effects of seed moisture content and threshing methods on bean (Phaseolus vulgaris L.) seed quality. Suleiman Demirel Universities Ziraat Faculties Dergisi 7 (1):51-57, 2012.

Zaalouk, A. K. (2009): Evaluation of local machine performance for threshing bean. . Misr J. of Agric. Eng., 26 (4): 1696-1709.

\section{الملخص العربـى}

اختيـار الظروف المناسبة لدراس العدس والفاصوليا د. محمـود مصطفى علي علي

يعد محصولى العدس والفاصوليا من أهم المحاصيل البقولية المستخدمة فى تغذية الإنسان

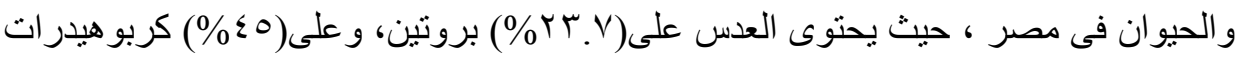

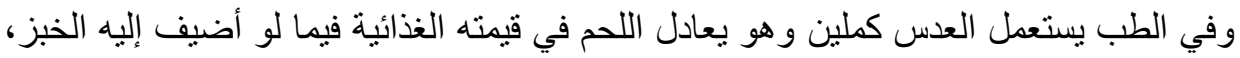

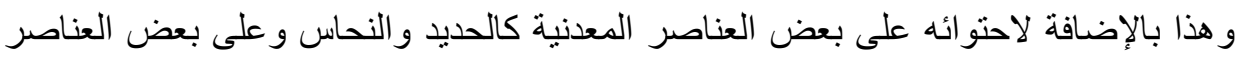

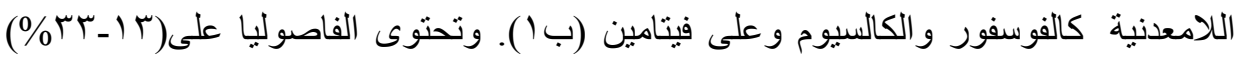

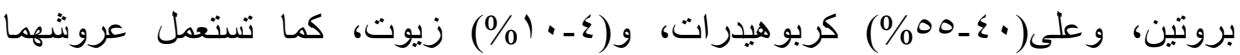

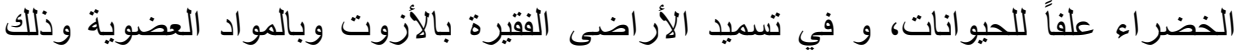

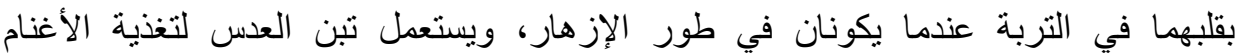

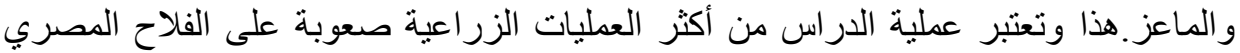

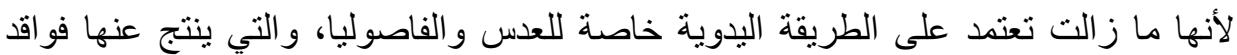

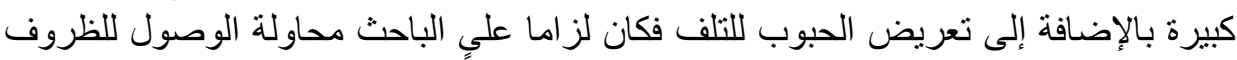

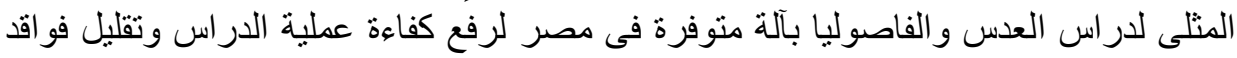

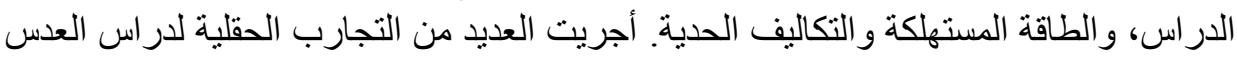

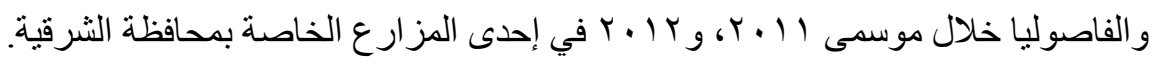

"أستاذ مساعد - قسم الهندسة الزراعية - كلية الزراعة - جامعة الزقازيق - مصر. 
وكان الهدف من الدراسة هو: اختيار الظروف المثلى لدراس العدس والفاصوليا (معدل التلقيم، سرعة درفيل الدراس، ونسبة رطوبة الحبوب). والثتملت الاراسة علي المتغيرات التالية:

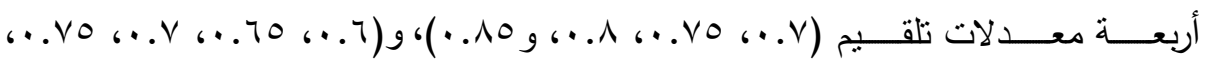

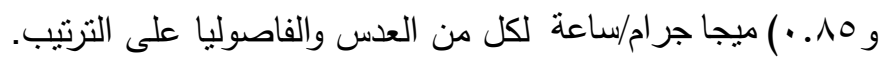

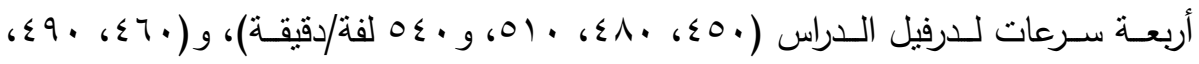

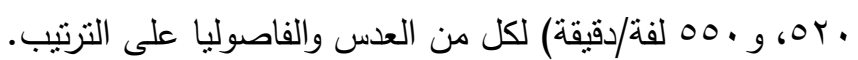

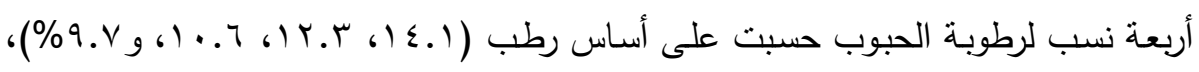

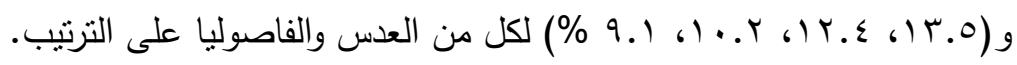
وقد تم تقييم المعاملات من حيث: نسبة الحبوب الغير مدروسة والمكسورة وفواقد الدراس. كفاءة الدراس والتتظيف. القدرة، والطاقة المستهلكة، والتكاليف الحدية لعملية الدراس. وقد أظهرت النتائج ما يلى:

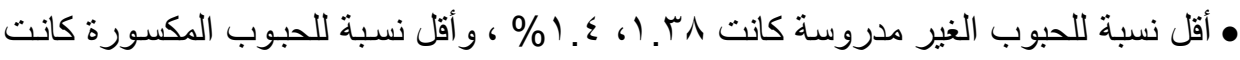

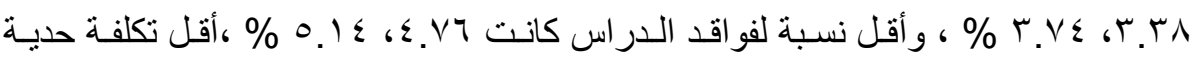

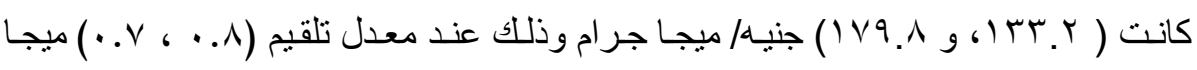

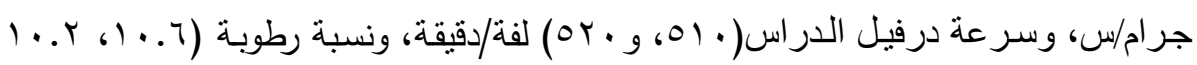
\%) لكل من العدس والفاصوليا على الترتيب.

ومن خلال النتائج تم التوصل إلى التوصيات الآتية لدراس العدس والفاصوليا على الترتيب:

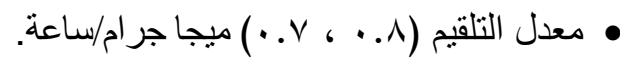

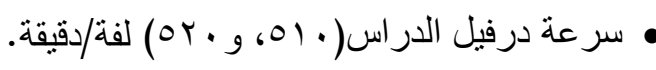

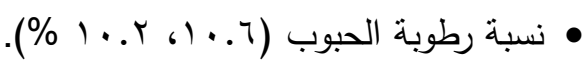

